\title{
Aminolysis of cyclic-carbonate vegetable oils as a non-isocyanate route for the synthesis of polyurethane: a kinetic and thermal study
}

Wander Y. Pérez-Sena ${ }^{1,2}$, Xiaoshuang Cai ${ }^{1}$, Nasreddine Kebir ${ }^{3}$, Lamiae Vernières-Hassimi ${ }^{1}$, Christophe Serra ${ }^{4}$,Tapio Salmi ${ }^{2}$, Sébastien Leveneur ${ }^{1,2^{*}}$

${ }^{I}$ Normandie Université LSPC-Laboratoire de Sécurité des Procédés Chimiques, EA4704, INSA/Université Rouen, BP08, Avenue de l'Université, 76801 Saint-Etienne-du-Rouvray,France; E-mail: sebastien.leveneur@insa-rouen.fr

${ }^{2}$ Laboratory of Industrial Chemistry and Reaction Engineering, Johan Gadolin Process Chemistry Centre, Åbo Akademi University, Biskopsgatan 8, FI-20500 Åbo/Turku, Finland.

${ }^{3}$ Normandie Université, INSA de Rouen, PBS UMR 6270 FR 3038 CNRS, INSA de Rouen, 685 Avenue de l'Université, 76801 Saint Etienne du Rouvray, France.

${ }^{4}$ Université de Strasbourg, CNRS, ICS UPR 22, 23 rue du Loess, BP84047, 67034 Strasbourg Cedex 2, France 


\begin{abstract}
Production of polyurethane is increasing since the recent years. Nevertheless, this production uses hazardous chemicals, which is isocyanate. Academy has put a lot of effort to develop some nonisocyante polyurethane routes. One of the most promising is the aminolysis of cyclic-carbonate by diamine. To industrialize this way of production, kinetic and thermodynamic data are needed. The first steps were to optimize the production of methyl oleate, epoxidized methyl oleate and carbonated methyl oleate. Then, a kinetic model was built for a model reaction which is the aminolysis of carbonated methyl oleate by n-butylamine by taking into account the side reaction of amidation. The model fits correctly the experimental data. A Tian-Calvet calorimeter was used to determine the different reaction enthalpies. It was found that the reactions of aminolysis and amidation were few exothermic.
\end{abstract}

Keywords: Polyurethane; Vegetable Oils; Kinetic Model; Calorimetry 


\section{Introduction}

In the last years, the production of polyurethane has significantly increased. The global production of this polymer was close to $20 \mathrm{Mt}$ in 2014 making it among the 6 polymers the most produced [1]. This is due to the versatile properties of polyurethanes (PUs). Indeed, the application of these polyurethane materials can be found in different fields such as ship industry, health sector, automotive or bedding $[2,3]$.

Production of PUs is commonly done by the reaction of polyols with di-isocyanates. Polyols can be produced from renewable feedstock like vegetable oils or their derivatives [4-6]. On the contrary, diisocyanate reactant is a petroleum -derived product from the reaction of an amine on phosgene, which is unstable and toxic [7]. Academic community has extensively studied the nonisocyanate route for the production of PUs and the cyclic-carbonate/amine route is more and more interesting for industry [8]. One of the most developed pathways is the reaction between a fivemembered bicyclocarbonate and a diamine [7, 9-17].

Synthesis of five-membered cyclic-carbonates can be done by several routes: reaction between $\mathrm{CO}_{2}$ and 1,2-diols [18] or between oxirane group and $\gamma$-butyrolactone [19]. The most common way for the production of cyclic-carbonates is the gas-liquid reaction between $\mathrm{CO}_{2}$ and oxirane groups [20-22].

Different research groups [8, 28-42] have studied the kinetics of aminolysis for cyclic-carbonate compounds. In the review of the non-isocyanate routes for the production of polyurethanes, Maissoneuve et al. [8] have summarized the kinetics of cyclic-carbonate aminolysis described in the following references [28-42]. It appears that the reaction is of second order in aprotic solvent, 
and the kinetics depends on the nature of the solvent. It was also pointed out that at higher reaction temperature, i.e., above $100{ }^{\circ} \mathrm{C}$, some side reactions can occur.

One can also cite the references of Levina et al. [41] and Lambeth and Henderson [42]. They have also noticed that the kinetics of reaction was of second order.

Except the work of Maisonneuve et al. [40], no studies were performed by using carbonated triglycerides or by using free fatty acids.

Aminolysis of carbonated vegetable oils for the production of polyurethane requires the knowledge of kinetic and thermodynamic data for an industrial scale-up. To the best of our knowledge, no such data can be found in the literature. The goal of this study is thus to fill this gap by developing a kinetic model for this reaction system. Aminolysis of carbonated methyl oleate by n-butylamine was chosen as a model system.

Fig. S1 shows the evolution of the viscosity with temperature for the different species, i.e., urethane, ester, epoxidized and carbonated. One can notice that the viscosity of oleic acid (OA) is higher than methyl oleate (MO). The viscosity increases using the epoxidized or carbonated forms. Thus, to avoid any mixing problem due to viscosity, oleic acid was esterified.

The first steps were to optimize the production of methyl oleate, epoxidized methyl oleate, and carbonated methyl oleate (Fig. 1). In the second part, a kinetic model was built by taking into account the amidation reaction, which is a side reaction.

HERE Fig. 1. Synthesis of methyl oleate based urethane. 


\section{Experimental section}

\subsection{Materials}

The following chemicals were used: oleic acid (purity $\geq 82 \mathrm{wt} \%$ ), methanol (purity $\geq 99 \mathrm{wt} \%$ ), formic acid (purity $>98 \mathrm{wt} \%$ ) and hydrogen peroxide (purity $\geq 33 \mathrm{wt} \%$ ) were purchased from VWR Chemicals. Sulfuric acid (purity $\geq 95$ wt $\%$ ) was obtained from AppliChem. Magnesium sulfate (purity $\geq 99.5 \mathrm{wt} \%$ ) was obtained from Sigma Aldrich. Tetrabutylammonium bromide (TBABr) and n-butyl amine (purity $\geq 99.5 \mathrm{wt} \%$ ) were supplied by Alfa Aesar.

\subsection{Analytical methods}

A gas chromatography (Bruker SCION 436-GC) equipped with a split injector and an elastic quartz capillary column (ZB-5, Phenomenex, $30 \mathrm{~m} \times 0.32 \mathrm{~mm}$ i.d., $0.25 \mu \mathrm{m}$ film thickness) was applied determine the conversion of oleic acid to methyl oleate in the esterification step (Fig. S2).

The yield of epoxide group during the epoxidation reaction was determined by the method of Jay [43], where oil samples were dissolved in a solution of $10 \mathrm{~mL}$ of tetra-n-etylammonium bromide (20 wt\% in acetic acid) and $10 \mathrm{~mL}$ of chloroform, then titrated with a TIM-840 automatic titrator (Radiometer Analytical, France) using a $0.1 \mathrm{~N}$ perchloric acid solution in acetic acid.

Otherwise, the conversion of unsaturated group was determined through titration of the iodine value using the method of Hanus [44]. Unsaturated group reacts with iodine monobromide forming halogenated single bonds. Then, a potassium iodine solution was added causing the reaction of the remaining unreacted iodine in sample, which forms molecular iodine. Molecular iodine presented in sample can be titrated using a standard solution of sodium thiosulfate $(0.1 \mathrm{~N})$ and ferroin indicator [45]. 
${ }^{1} \mathrm{H}-\mathrm{NMR}$ spectra were recorded on a Bruker 300 Fourier transform spectrometer at $300 \mathrm{MHz}$ in $\mathrm{CDCl}_{3}$ solutions using tetramethylsilane (TMS) as internal standard.

IR spectra were recorded on a FTIR (Perkin-Elmer Spectrum 2000 FTIR), equipped with a diamond ATR device (Attenuated Total Reflection). Spectra were obtained from 10 scans in the (4000 to 500) $\mathrm{cm}^{-1}$ range. The enthalpies of reaction were measured using a Tian-Calvet heat flow calorimeter C80 (Setaram, France).

Viscosity measurement was performed with the aid of a Höppler viscometer (Fungilab S/A, Barcelona, Spain).

It was found that there is a linear relationship between the concentrations of ester and carbonated groups and their corresponding intensity signals from FTIR-analyses (eqs (1-2)).

$[$ Carbonated $]=\mathrm{A}_{\text {Carb }} \cdot A b s_{1802 \mathrm{~cm}^{-1}}+\mathrm{B}_{\text {Carb }}$

$[$ Ester $]=\mathrm{A}_{\text {Ester }} \cdot A b s_{1738 \mathrm{~cm}^{-1}}+\mathrm{B}_{\text {Ester }}$

where, [Carbonated $]$ and [Ester] stand for the concentration of carbonated group and ester group. $\mathrm{A}_{\mathrm{i}}$ and $\mathrm{B}_{\mathrm{i}}$ are characteristic constants of the FTIR equipment; $A b s$ is the intensity of the signal at the corresponding wavelength. Figs. S3 and S4 show the linear correlation between the concentrations of ester and carbonated groups. 


\subsection{Production of intermediates}

\subsubsection{Oleic acid esterification}

The reaction was carried out in a $500 \mathrm{~mL}$ reactor equipped with a mechanical stirrer and reflux condenser. Oleic acid (OA), methanol and sulfuric acid were mixed at a constant temperature of $64{ }^{\circ} \mathrm{C}$ with the following molar percentage: $19.2 \%, 79.8 \%$ and $1.0 \%$, respectively [46]. The reaction took $3 \mathrm{~h}$. Next, the mixture was washed five times with preheated distillated water. Then, the organic phase left in the reactor was evaporated using an IKA RV10 control vacuum rotary evaporator (VWR, Darmstadt, Germany) at $70{ }^{\circ} \mathrm{C}$ and dried over anhydrous magnesium sulfate. The final products were analyzed by FITR, GC (Fig. S2) and ${ }^{1} \mathrm{H}-\mathrm{NMR}$ analysis.

\subsubsection{Epoxidation of methyl oleate}

The preparation of epoxidized methyl oleate (EMO) from methyl oleate (MO) was carried out in a $500 \mathrm{~mL}$ glass-jacketed reactor equipped with a mechanical stirrer and reflux condenser. The epoxidation was conducted in semi-batch mode, methyl oleate and formic acid were mixed at $40{ }^{\circ} \mathrm{C}$, then hydrogen peroxide was added with a volumetric flow rate of $7.3 \mathrm{~mL} \cdot \mathrm{min}^{-1}$ for $1 \mathrm{~h}$. The methyl oleate:formic acid:hydrogen peroxide molar ratio was 1:2:13. The reaction was performed for $4 \mathrm{~h}$. The organic layer (containing the epoxide groups) was separated and washed with water to remove residual $\mathrm{H}_{2} \mathrm{O}_{2}$ and acids, followed by evaporation and dried over anhydrous magnesium sulfate [46]. Fig. 2 illustrates a simplified scheme of the reactor setup.

HERE Fig. 2. Simplified reactor scheme for the epoxidation. 


\subsubsection{Carbonation of epoxidized methyl oleate}

The carbonated methyl oleate (CMO) was prepared in a $300 \mathrm{~mL}$ autoclave equipped with a mechanical stirrer under pressure of carbon dioxide, TBABr was used as catalyst. Fig. 3 shows a simplified scheme of the reactor setup. Based on recent investigations [23, 25, 27, 47-49], the optimum process conditions for carbonation reaction were $130{ }^{\circ} \mathrm{C}, 30$ bar of $\mathrm{CO}_{2}$ pressure with a catalyst loading of $7 \mathrm{~mol} \%$. After eight hours of reaction, the conversion of epoxide group was $99 \%$. The resulting CMO was diluted in ethyl acetate, and washed four times with distilled water in order to remove $\mathrm{TBABr}$ catalyst, the product was dried with a rotary evaporator at $70{ }^{\circ} \mathrm{C}$, and then anhydrous magnesium sulfate was used to dry traces of water before the aminolysis [50].

\section{HERE Fig. 3. Simplified reactor scheme for the carbonation.}

\subsection{Aminolysis reaction}

Aminolysis was carried out under semi-batch mode in a $300 \mathrm{~mL}$ reactor equipped with a mechanical stirrer and a reflux condenser by reacting carbonated methyl oleate (CMO) and $n$-butyl amine (nBA) to produce urethanized methyl oleate (UMO). The latter reactant was added dropwise to avoid rapid temperature increase. The reactor setup is similar to the one shown in Fig. 2. The influences of temperature and feed flow rate were studied. The concentrations of urethane and ester groups were estimated by FTIR analysis. Indeed, there is a side reaction, which is the amidation of the ester groups $[8,51-52]$. The products were also characterized by titration and ${ }^{1} \mathrm{H}-$ NMR analysis.

The experimental matrix used for the parameter estimation is displayed in Table 1 . The term $Q_{\text {feed }}$ stands for the volumetric flow rate of n-butylamine. 


\section{HERE Table 1. Experimental matrix.}

\subsection{Calorimetry}

Reaction enthalpies were measured in a Tian-Calvet calorimeter (C80 Setaram) under isothermal mode. It is a twin calorimeter with a measured and reference cells in reversal mode. Fig. 4 shows a schematic view of the setup inside the calorimeter. Approximately 1 gram of sample was inserted in both the reference and measuring cells. Once the temperature and the flow heat rate in the cells were stable, the reaction was started. The heat flow released during the reaction course is due to the chemical reaction. More information about this system can be found in the references of our group [53-55].

To determine the reaction enthalpies of aminolysis and amidation, two experiments were performed.

In the first experiment, the measurement cell was filled with $\mathrm{CMO}$ in one compartment and with n-butylamine in the other one, and the reference cell was filled with CMO in one compartment and with ethyl acetate in the other one (Fig. 4a). Ethyl acetate was chosen because it does not react with $\mathrm{CMO}$ and has similar specific heat capacity, as is the case with n-butylamine. Since there are no reactions in the reference cell, the total energy released by the system was the one for aminolysis and amidation reactions.

In the second experiment, the measurement cell was filled with CMO in one compartment and with n-butylamine in the other one, and the reference cell was filled with methyl oleate (MO) in one compartment and with n-butylamine in the other one (Fig. 4b). In the reference cell, amidation reaction also occurred, thus, the total energy released by the system was the one for aminolysis reaction. 
HERE Fig. 4. Reversal mixing cells of C80 calorimeter. 


\section{Results and discussion}

\subsection{Product characterization}

\subsubsection{Oleic acid esterification}

Since the esterification is a reversible reaction [56], a large molar excess of methanol was used to favor the ester formation. The maximum yield obtained was $93 \%$ confirmed by GC analysis. Fig. 5 shows the FTIR spectra of oleic acid (OA) and methyl oleate (MO). The absorption band of ester group is at $1738 \mathrm{~cm}^{-1}$, which confirms the production of methyl oleate during the reaction. Otherwise, the band at $1710 \mathrm{~cm}^{-1}$ corresponds to carbonyl of residual acid groups. ${ }^{1} \mathrm{H}-\mathrm{NMR}$ spectra (Fig. 6) also confirm the quantitative conversion of oleic acid to methyl oleate from the emergence of the corresponding signal of methyl ester group at $3.66 \mathrm{ppm}$ as well as from the displacement of the signal of methylene group in alpha position to acid group from $2.34 \mathrm{ppm}$ to $2.29 \mathrm{ppm}$.

HERE Fig. 5. FTIR-spectra for OA, MO, EMO, CMO and UMO. 


\subsubsection{Epoxidation of methyl oleate}

The concentration of epoxide groups was followed by titration using a $0.1 \mathrm{~mol} . \mathrm{L}^{-1}$ perchloride acid solution. The maximum concentration was reached after $4 \mathrm{~h}$, with an epoxy yield of $91 \%$ and a conversion of $98 \%$ for double bonds. To minimize the side reaction of ring-opening, the most appropriate time was $4 \mathrm{~h}$. The FTIR spectra of epoxidized methyl oleate (Fig. 5) shows the appearance of bands between $815-950 \mathrm{~cm}^{-1}$, which are related to stretching vibration of epoxide groups. Compared to methyl oleate, the disappearance of the band in the range of $3000-3050 \mathrm{~cm}^{-}$

${ }^{1}$ showed that the unsaturated groups were consumed [57]. Furthermore, ${ }^{1} \mathrm{H}-\mathrm{NMR}$ revealed that the signal at $5.34 \mathrm{ppm}$ arising from carbon-carbon double bonds has disappeared (Fig. 6). Epoxide formation was confirmed by the appearance of a signal at $2.90 \mathrm{ppm}$ [46].

HERE Fig. $6 .{ }^{1} \mathrm{H}-\mathrm{NMR}$ for OA, MO, EMO, CMO and UMO.

\subsubsection{Carbonation of Epoxidized methyl oleate}

As illustrated in Fig. 7, CMO was prepared by converting the epoxide group of EMO with carbon dioxide in the presence of $\mathrm{TBABr}$ as catalyst. The oxirane ring of methyl oleate was attacked by the bromide of the catalyst leading to ring opening, followed by the nucleophilic attack of the alkoxide. Then, the five-membered carbonate was produced by the ring closure reaction of the resulting carboxylate $[50,58-60]$.

HERE Fig. 7. Conversion of epoxidized methyl oleate to carbonated methyl oleate. 
The optimum conditions (load of catalyst, pressure, temperature) for the carbonation reaction have been studied before, concluding that a catalyst loading higher than $7 \mathrm{~mol} \%$ barely increases the conversion rate [46]. During the investigation made by Ait Aissa et al. [26], a thermal stability analysis of the catalyst was carried out, and it was found that temperature higher than $130{ }^{\circ} \mathrm{C}$ can cause a decomposition of $\mathrm{TBABr}$, and subsequently the diminution of selectivity due to the formation of undesired secondary products. In this sense, the conditions for the carbonation of epoxidized methyl oleate were carefully optimized, with a temperature of $130{ }^{\circ} \mathrm{C}$ and a fixed pressure of 30 bar. A reaction time of 8 hours was selected, resulting in a $99 \%$ conversion of epoxide groups.

The FTIR spectrum of CMO (Fig. 5) shows a strong band at $1800 \mathrm{~cm}^{-1}$ corresponding to the carbonate group. This band has a similar height with the one of ester group at $1738 \mathrm{~cm}^{-1}$, which denotes similar concentration according to the literature [48], and that the yield of carbonated group is high. The absence of absorption bands of epoxide group between $815-950 \mathrm{~cm}^{-1}$ confirms the fact that the conversion of epoxide group to carbonated groups is high. ${ }^{1} \mathrm{H}-\mathrm{NMR}$ spectra showed signals between 4.40-4.95 ppm assigned to carbonated groups [43]. 


\subsubsection{Aminolysis reaction of carbonated methyl oleate}

Fig. 1 shows the reaction of carbonated methyl oleate with n-butylamine. In this reaction system, two reactions occur: aminolysis, and amidation as a side reaction. The products were analyzed by FTIR and ${ }^{1} \mathrm{H}-\mathrm{NMR}$ analysis. Fig. 5 shows the decrement of signal at $1802 \mathrm{~cm}^{-1}$ corresponding to some unreacted carbonated groups. It was also noticeable new absorption bands at $1720 \mathrm{~cm}^{-1}$ and $1647 \mathrm{~cm}^{-1}$, which are typical for urethane and amide groups [19]. The conversion of carbonated groups was also confirmed through ${ }^{1} \mathrm{H}-\mathrm{NMR}$ (Fig. 6) through the disappearance of the cycliccarbonate signals at $4.22 \mathrm{ppm}$ and $4.61 \mathrm{ppm}$. In the range of $4.8-5.2 \mathrm{ppm}$, the broad signal is assigned to protons of $\mathrm{NH}$ and those in alpha position to the oxygen of the urethane function. Protons in alpha to the nitrogen of this function arised at $3.16 \mathrm{ppm}$. The signal at $3.55 \mathrm{ppm}$ is ascribed to protons in alpha position to hydroxyl groups. These correlations are in quite consistency with those of Tryznowski et al. [61] and Meng et al. [62]. 


\subsection{Calorimetry results}

The evolution of the heat-flow rate as function of time is depicted in Fig. 8a. It stands for the overall energy released due to urethane formation and to amide formation at $60{ }^{\circ} \mathrm{C}$. Fig. $8 \mathrm{~b}$ shows the heat released only during the formation of urethanes at $60{ }^{\circ} \mathrm{C}$.

HERE Fig. 8.a Heat profiles for CMO and n-butylamine system at $60^{\circ} \mathrm{C}$. b. Heat profile for the production of urethanes at $60{ }^{\circ} \mathrm{C}$.

By integrating the curves in Fig. 8a, the overall enthalpy of the reactional system (amidation + aminolysis) was found to be $-23.90 \mathrm{~kJ}$ per mole of carbonated group. Then, the corresponding integration of heat-flow rate shown in Fig. 8b provides the enthalpy due to the formation of urethanes, which was found to be $-18.92 \mathrm{~kJ} \cdot \mathrm{mol}^{-1}$. Thus, the enthalpy of amidation is $-5.02 \mathrm{~kJ} \cdot \mathrm{mol}^{-}$ 1. These reaction enthalpies indicate that these reactions are not very exothermic. 


\subsection{Kinetic model}

In order to monitor the evolution of the reaction system in a quantitative way, samples were analyzed by FTIR spectroscopy during the reaction (Eqs (1-2)). These experimental data were used to estimate the kinetic constants of the production of urethane and amide groups.

\section{Kinetics}

Aminolysis reaction was considered as an elementary reaction. Amidation is a reversible reaction. Thus, their kinetic rate equations were expressed as

$R_{\text {Aminol }}=k_{\text {Aminol }} \times[$ Carbonated $][n B A]$

$R_{\text {Amid }}=k_{\text {Amid }} \times\left([\right.$ Ester $\left.][n B A]-\frac{[\text { Amide }][\mathrm{MeOH}]}{K_{c}}\right)$

where, $R_{\text {Aminol }}$ and $R_{\text {Amid }}$ represent the reaction rate of aminolysis and amidation reaction, $k_{\text {Aminol }}$ and $k_{\text {Amid }}$ stand for the kinetic constants of aminolysis and amidation reaction and [Carbonated], [Ester], $[n B A]$, and [Amide] are the concentrations of carbonated group, ester group, $\mathrm{n}$-butyl amine, and amide group, respectively. $K_{c}$ is the equilibrium constant for the amidation reaction.

The evolution of $K_{c}$ can be expressed by a van't Hoff's law:

$K_{c}\left(T_{R}\right)=K_{c}\left(T_{\mathrm{Ref}}\right) \times \exp \left(\frac{-\Delta H_{R, A m i d}}{R} \times\left(\frac{1}{T_{R}}-\frac{1}{T_{\mathrm{Ref}}}\right)\right)$

where, $T_{R}$ and $T_{R e f}$ represent the reaction temperature and reference temperature and $R$ is the universal gas constant and $\Delta H_{R, A m i d}$ is the enthalpy of the amidation reaction, which was found

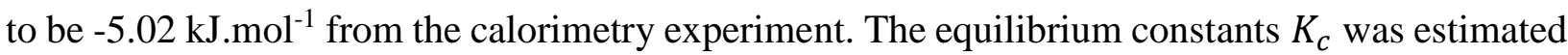
at a reference temperature of $70{ }^{\circ} \mathrm{C}$. 
Mass Balance

A simplified scheme of the aminolysis is shown in Fig. 9.

HERE Fig. 9. Aminolysis of carbonated methyl oleate.

The volumetric flow rate was constant during the addition time, thus, one gets

$\frac{d V_{r}}{d t}=Q_{\text {feed }}$ for $t<\mathrm{t}_{a d d}$ and $\frac{d V_{r}}{d t}=0 \mathrm{~L} . \mathrm{s}^{-1}$ for $\mathrm{t}>t_{a d d}$

where, $Q_{\text {feed }}$ is the volumetric flow rate, $t_{a d d}$ is the addition time and $V_{r}$ is the volume of the reaction.

Ordinary differential equation 6 was used to simulate the evolution of the reactor volume.

Mass balance for all compounds in the reaction system can be expressed as:

$\frac{d[\text { Carbonated }]}{d t}=-R_{\text {Aminol }}-[$ Carbonated $] \times \frac{Q_{\text {feed }}}{V_{r}}$

$\frac{d[n B A]}{d t}=-\left(R_{\text {Aminol }}+R_{\text {Amid }}\right)+\left([n B A]_{\text {feed }}-[n B A]\right) \times \frac{Q_{\text {feed }}}{V_{r}}$

$\frac{d[U M O]}{d t}=R_{\text {Aminol }}-[U M O] \times \frac{Q_{\text {feed }}}{V_{r}}$

$\frac{d[\text { Ester }]}{d t}=-R_{\text {Amid }}-[$ Ester $] \times \frac{Q_{\text {feed }}}{V_{r}}$

$\frac{d[\text { Amide }]}{d t}=R_{\text {Amid }}-[$ Amide $] \times \frac{Q_{\text {feed }}}{V_{r}}$

$\frac{d[\mathrm{MeOH}]}{d t}=R_{\text {Amid }}-[\mathrm{MeOH}] \times \frac{Q_{\text {feed }}}{V_{r}}$

where, $[U M O]$ and $[\mathrm{MeOH}]$ are the concentration of urethanized methyl oleate and methanol, respectively. 


\section{Parameter estimation}

For the estimation of the kinetic constants, the software MODEST was used [63]. The ordinary differential equations ODEs (6-12) were solved out by the ODESSA algorithm based on backward difference methods.

Concentrations of ester and carbonated groups were used as observables. The objective function $\theta$ was minimized by the Simplex and Levenberg-Marquardt algorithms.

$\theta=\sum\left(C_{i}-\widehat{C}_{\imath}\right)$

where, $C_{i}$ is the experimental concentration and $\widehat{C}_{l}$ is the concentration simulated by the model.

To define the reliability of the model to the experimental data, the following coefficient of explanation was defined as

$R^{2}=1-\frac{\sum\left(C_{i}-\hat{C}_{i}\right)^{2}}{\sum\left(C_{i}-\bar{C}_{i}\right)^{2}}$

where, $\bar{C}_{i}$ is the average value of the experimental concentration. The coefficient of explanation was higher than $90 \%$, which means that the model is correct.

To minimize the dependency between the activation energy and the pre-exponential factor, rate constants were expressed by using a modified Arrhenius equation.

$k_{i}\left(T_{R}\right)=k_{i}\left(T_{\mathrm{Ref}}\right) \times \exp \left(\frac{-E_{a_{i}}}{R}\left(\frac{1}{T_{R}}-\frac{1}{T_{\mathrm{Ref}}}\right)\right)$

where, $k_{i}$ is reaction rate constant, $E_{a}$ is the activation energy, $T_{R}$ represents the reaction temperature and reference temperature, $R$ is the universal gas constant and $T_{\text {Ref }}$ was fixed to $66.85^{\circ} \mathrm{C}$ in our study. 
Table 2 presents the values of the estimated parameters with associated standard deviations. The standard errors were estimated within $95 \%$ of the confidence interval. One can notice that the standard deviations are low for the kinetic constants. For the equilibrium constant $K_{C}$ for the amidation reaction at $70{ }^{\circ} \mathrm{C}$, the standard deviation is of $78 \%$ due to the complexity to estimate such thermodynamic parameters. Nevertheless, this deviation is still acceptable.

HERE Table 2. Kinetic constants estimated at $66.85^{\circ} \mathrm{C}$ and statistical data.

The results of the kinetic modeling are presented in Figs. 10a-10f. One can notice that the model fits correctly the experimental concentration of carbonated and ester groups. For the sake of information, the simulated concentrations of amide and urethane were also plotted. Figs. 11a-11b shows the contour plot for the estimated kinetic and activation energy constants for both reactions. It is clear that the minimum of the objective function was reached. 
HERE Fig. 10a. Fit of the model for the aminolysis of $\mathrm{CMO}$ at $40^{\circ} \mathrm{C}$ and $4 \mathrm{~mL} \cdot \mathrm{min}^{-1}$.

HERE Fig. 10b. Fit of the model for the aminolysis of $\mathrm{CMO}$ at $60^{\circ} \mathrm{C}$ and $1 \mathrm{~mL} \cdot \mathrm{min}^{-1}$.

HERE Fig. 10c. Fit of the model for the aminolysis of $\mathrm{CMO}$ at $70^{\circ} \mathrm{C}$ and $1 \mathrm{~mL} \cdot \mathrm{min}^{-1}$.

HERE Fig. 10d. Fit of the model for the aminolysis of $\mathrm{CMO}$ at $50{ }^{\circ} \mathrm{C}$ and $2 \mathrm{~mL} \cdot \mathrm{min}^{-1}$.

HERE Fig. 10e. Fit of the model for the aminolysis of $\mathrm{CMO}$ at $50{ }^{\circ} \mathrm{C}$ and $4 \mathrm{~mL} \cdot \mathrm{min}^{-1}$.

HERE Fig. 10f. Fit of the model for the aminolysis of $\mathrm{CMO}$ at $50{ }^{\circ} \mathrm{C}$ and $3 \mathrm{~mL} \cdot \mathrm{min}^{-1}$.

HERE Fig. 11a. Contour plot of kinetic parameters for the aminolysis.

HERE Fig. 11b. Contour plot of kinetic parameters for the side reaction of amidation. 


\section{Conclusion}

The use of cyclic-carbonate such as carbonated vegetable oils and amine represents a greener and safer way for the production of non-isocyanate polyurethane. Several articles have discussed about this way of production but few of them have proposed a kinetic model. The goal of this article was to build a kinetic model for a model reaction: aminolysis of carbonated methyl oleate with nbutylamine.

In the first part of this study, the esterification and epoxidation steps were optimized to have the maximum yield in ester and epoxide groups. In the second part, several experiments of aminolysis were performed under isothermal mode in a semi-batch reactor. A Tian-Calvet calorimeter was used to determine the enthalpies of amidation and aminolysis reactions. It was found that these reactions are not very exothermic, i.e., $\Delta H_{R, A m i d}=-5.02 \mathrm{~kJ} \cdot \mathrm{mol}^{-1}$ and $\Delta H_{R, A m i n o l}=$ $-18.92 \mathrm{~kJ} \cdot \mathrm{mol}^{-1}$.

A kinetic model was built by taking into account the aminolysis reaction and the side reaction of amidation. A non-linear regression method was used to estimate the kinetic constants for these two reactions by using the experimental concentrations of ester and carbonated groups as observable. The model fits quite well with the experimental concentrations.

In order to shift to industrial application, aminolysis of carbonated vegetable oils with diamines should be the continuation of this study. 


\section{Notation}

\begin{tabular}{|c|c|}
\hline Amide & amide groups \\
\hline Carbonated & carbonated groups \\
\hline Carb & carbonation reaction \\
\hline Ester & ester group \\
\hline$E_{a}$ & activation energy $\left[\mathrm{kJ} \cdot \mathrm{mol}^{-1}\right]$ \\
\hline FTIR & fourier transform infrared spectroscopy \\
\hline${ }^{1} \mathrm{H}-\mathrm{NMR}$ & proton nuclear magnetic resonance \\
\hline$\Delta H_{R}$ & reaction enthalpy $\left[\mathrm{kJ} \cdot \mathrm{mol}^{-1}\right]$ \\
\hline$k_{i}$ & reaction rate constant or kinetic constant $\left[\mathrm{L} \cdot \mathrm{mol}^{-1} \cdot \mathrm{s}^{-1}\right]$ \\
\hline$K_{c}$ & equilibrium constant \\
\hline $\mathrm{MeOH}$ & methanol \\
\hline$Q_{\text {feed }}$ & volumetric flow rate $\left[\mathrm{L} \cdot \mathrm{s}^{-1}\right]$ \\
\hline$R_{i}$ & reaction rate $\left[\mathrm{mol} \cdot \mathrm{L}^{-1} \cdot \mathrm{s}^{-1}\right]$ \\
\hline$R$ & universal gas constant \\
\hline$r$ & reaction rate for a reactant or product $\left[\mathrm{mol} \cdot \mathrm{L}^{-1} . \mathrm{s}^{-1}\right]$ \\
\hline$T$ & temperature $[\mathrm{K}]$ \\
\hline$t_{\text {add }}$ & addition time $[\mathrm{s}]$ \\
\hline$V_{r}$ & volume of reaction $[\mathrm{L}]$ \\
\hline$C_{i}$ & experimental concentration $\left[\mathrm{mol} . \mathrm{L}^{-1}\right]$ \\
\hline$\widehat{C}_{l}$ & simulated concentration $\left[\mathrm{mol} . \mathrm{L}^{-1}\right]$ \\
\hline
\end{tabular}


Subscripts and superscripts

0

add

Amid

Aminol

feed

$i$

$r$

Abbreviations

CMO

EMO

MO

$U M O$

$n B A$

$O A$

$T B A B r$

$\mathrm{MeOH}$ initial

addition

amidation

aminolysis

feed

component i

reactor

carbonated methyl oleate

epoxidized methyl oleate

methyl oleate

urethanized methyl oleate

n-butylamine

oleic acid

tetra-n-butylammonium bromide

methanol 


\section{Tables}

Table 1. Experimental matrix.

Table 2. Kinetic constants estimated at $66.85{ }^{\circ} \mathrm{C}$ and statistical data.

\section{Figures}

Fig. 1. Synthesis of methyl oleate based urethane.

Fig. 2. Simplified reactor scheme for the epoxidation.

Fig. 3. Simplified reactor scheme for the carbonation.

Fig. 4. Reversal mixing cells of C80 calorimeter.

Fig. 5. FTIR-spectra for OA, MO, EMO, CMO and UMO.

Fig. 6. ${ }^{1} \mathrm{H}-\mathrm{NMR}$ for OA, MO, EMO, CMO and UMO.

Fig. 7. Conversion of epoxidized methyl oleate to carbonated methyl oleate.

Fig. 8. a) Heat profiles for $\mathrm{CMO}$ and n-butylamine system at $60^{\circ} \mathrm{C}$. b) Heat profile for the production of urethanes at $60{ }^{\circ} \mathrm{C}$.

Fig. 9. Aminolysis of carbonated methyl oleate.

Fig. 10a. Fit of the model for the aminolysis of $\mathrm{CMO}$ at $40{ }^{\circ} \mathrm{C}$ and $4 \mathrm{~mL} \cdot \mathrm{min}^{-1}$.

Fig. 10b. Fit of the model for the aminolysis of $\mathrm{CMO}$ at $60{ }^{\circ} \mathrm{C}$ and $1 \mathrm{~mL} \cdot \mathrm{min}^{-1}$.

Fig. 10c. Fit of the model for the aminolysis of $\mathrm{CMO}$ at $70^{\circ} \mathrm{C}$ and $1 \mathrm{~mL} \cdot \mathrm{min}^{-1}$.

Fig. 10d. Fit of the model for the aminolysis of $\mathrm{CMO}$ at $50{ }^{\circ} \mathrm{C}$ and $2 \mathrm{~mL} \cdot \mathrm{min}^{-1}$.

Fig. 10e. Fit of the model for the aminolysis of $\mathrm{CMO}$ at $50{ }^{\circ} \mathrm{C}$ and $4 \mathrm{~mL} \cdot \mathrm{min}^{-1}$.

Fig. 10f. Fit of the model for the aminolysis of $\mathrm{CMO}$ at $50{ }^{\circ} \mathrm{C}$ and $3 \mathrm{~mL} \cdot \mathrm{min}^{-1}$.

Fig. 11a. Contour plot of kinetic parameters for the aminolysis.

Fig. 11b. Contour plot of kinetic parameters for the side reaction of amidation. 


\section{Acknowledgments}

The authors thank the Ministry of High Education, Science and Technology of Dominican Republic. The authors thank the Maîtrise des Risques et Environnementaux department. 


\section{References}

[1] E. Orgiles-Calpena, F. Aran-Ais, A.M. Torro-Palau, E. Montiel-Parreno, C. Orgiles-Barcelo, Synthesis of polyurethanes from $\mathrm{CO}_{2}$-based polyols: A challenge for sustainable adhesives, Int. J. Adhes. Adhes. 67 (2016) 63-68. doi:10.1016/j.ijadhadh.2015.12.027.

[2] G, Woods, The ICI Polyurethanes book, 2nd ed., Wiley, New York, 1990.

[3] M. Stanzione, V. Russo, A. Sorrentino, R. Tesser, M. Lavorgna, M. Oliviero, M. Di Serio, S. Iannace, L. Verdolotti, Bio-based polyurethane foams from renewable resources, AIP Conference Proceedings 1736, 020130 (2016). doi: 10.1063/1.4949705.

[4] E. Pardieu, N. Trang Thanh Chau, T. Dintzer, T. Romero, D. Favier, T. Roland, D. Edouard, L. Jierry, V. Ritleng, Polydopamine-coated open cell polyurethane foams as an inexpensive, flexible yet robust catalyst support: a proof of concept, Chem. Commun. 52 (2016), 4691-4693. doi: $10.1039 / \mathrm{c} 6 \mathrm{cc} 00847 \mathrm{j}$.

[5] Z.S. Petrovic, Polyurethanes from vegetable oils, Polym. Rev. 48 (2008) 109-155. doi:10.1080/15583720701834224.

[6] G. Lligadas, Renewable Polyols for Polyurethane Synthesis via Thiol-ene/yne Couplings of Plant Oils, Macromol. Chem. Phys. 214 (2013) 415-422. doi:10.1002/macp.201200582.

[7] O. Kreye, H. Mutlu, M.A.R. Meier, Sustainable routes to polyurethane precursors, Green Chem. 15 (2013) 1431-1455. doi:10.1039/C3GC40440D.

[8] L. Maisonneuve, O. Lamarzelle, E. Rix, E. Grau, H. Cramail, Isocyanate-Free Routes to Polyurethanes and Poly(hydroxy Urethane)s, Chem. Rev. 115 (2015) 12407-12439. doi:10.1021/acs.chemrev.5b00355. 
[9] H. Tomita, F. Sanda, T. Endo, Polyaddition of bis(seven-membered cyclic carbonate) with diamines: A novel and efficient synthetic method for polyhydroxyurethanes, J. Polym. Sci. A Polym. Chem. 39 (2001) 4091-4100. doi:10.1002/pola.10058.

[10] E. Del Rio, G. Lligadas, J.C. Ronda, M. Galia, V. Cadiz, Biobased Polyurethanes from Polyether Polyols Obtained by Ionic-Coordinative Polymerization of Epoxidized Methyl Oleate, J. Polym. Sci. Pol. Chem. 48 (2010) 5009-5017. doi:10.1002/pola.24296.

[11] B. Ochiai, K. Koda, T. Endo, Branched cationic polyurethane prepared by polyaddition of chloromethylated five-membered cyclic carbonate and diethylenetriamine in molten salts, $\mathrm{J}$. Polym. Sci. A Polym. Chem. 50 (2012) 47-51. doi:10.1002/pola.24969.

[12] P. Deepa, M. Jayakannan, Solvent-induced self-organization approach for polymeric architectures of micropores, hexagons and spheres based on polyurethanes prepared via novel melt transurethane methodology, J. Polym. Sci. Pol. Chem. 45 (2007) 2351-2366. doi:10.1002/pola.22058.

[13] B. Ochiai, H. Kojima, T. Endo, Synthesis and properties of polyhydroxyurethane bearing silicone backbone, J. Polym. Sci. Part A: Polym. Chem. 52 (2014) 1113-1118. doi:10.1002/pola.27091.

[14] M.S. Kathalewar, P.B. Joshi, A.S. Sabnis, V.C. Malshe, Non-isocyanate polyurethanes: from chemistry to applications, RSC Adv. 3 (2013) 4110-4129. doi:10.1039/C2RA21938G.

[15] C. Duval, N. Kebir, R. Jauseau, F. Burel, Organocatalytic synthesis of novel renewable nonisocyanate polyhydroxyurethanes, J. Polym. Sci. Pol. Chem. 54 (2016) 758-764. doi:10.1002/pola.27908.

[16] A. Cornille, R. Auvergne, O. Figovsky, B. Boutevin, S. Caillol, A perspective approach to sustainable routes for non-isocyanate polyurethanes, Eur. Polym. J. 87 (2017) 535-552. doi: 10.1016/j.eurpolymj.2016.11.027. 
[17] O. Figovsky, A. Leykin, L. Shapovalov, Non-isocyanate polyurethanes - yesterday, today and tomorrow, ISJAEE 3 (2016) 95-108. doi: 10.15518/isjaee.2016.03-04.009.

[18] F. Zhao, Method for synthesizing propylene carbonate ester from $\mathrm{CO}_{2}$ and 1, 2-propanediol, $\mathrm{CN}$ 101376632 A, 2009.

[19] T. Nishikubo, T. Iizawa, M. Iida, N. Isobe, Convenient syntheses of cyclic carbonates by new reaction of oxiranes with $\beta$-butyrolactone, Tetrahedron Lett. 27 (1986) 3741-3744. doi:10.1016/S0040-4039(00)83868-X.

[20] M. Fleischer, H. Blattmann, R. Mülhaupt, Glycerol-, pentaerythritol- and trimethylolpropanebased polyurethanes and their cellulose carbonate composites prepared via the non-isocyanate route with catalytic carbon dioxide fixation, Green Chem. 15 (2013) 934-942. doi:10.1039/C3GC00078H.

[21] M. Bähr, R. Mülhaupt, Linseed and soybean oil-based polyurethanes prepared via the nonisocyanate route and catalytic carbon dioxide conversion, Green Chem. 14 (2012) 483-489. doi:10.1039/C2GC16230J.

[22] S. Foltran, L. Maisonneuve, E. Cloutet, B. Gadenne, C. Alfos, T. Tassaing, H. Cramail, Solubility in $\mathrm{CO}_{2}$ and swelling studies by in situ IR spectroscopy of vegetable-based epoxidized oils as polyurethane precursors, Polym. Chem. 3 (2012) 525-532. doi:10.1039/c2py00476c.

[23] A. Boyer, E. Cloutet, T. Tassaing, B. Gadenne, C. Alfos, H. Cramail, Solubility in $\mathrm{CO}_{2}$ and carbonation studies of epoxidized fatty acid diesters: towards novel precursors for polyurethane synthesis, Green Chem. 12 (2010) 2205-2213. doi:10.1039/C0GC00371A.

[24] M. Bähr, A. Bitto, R. Mülhaupt, Cyclic limonene dicarbonate as a new monomer for nonisocyanate oligo- and polyurethanes (NIPU) based upon terpenes, Green Chem. 14 (2012) 14471454. doi:10.1039/C2GC35099H. 
[25] X. Cai, J.L. Zheng, J. Wärnå, T. Salmi, B. Taouk, S. Leveneur, Influence of gas-liquid mass transfer on kinetic modeling: Carbonation of epoxidized vegetable oils, Chem. Eng. J. 313 (2017) 1168-1183. doi:10.1016/j.cej.2016.11.012.

[26] K. Ait Aissa, J.L. Zheng, L. Estel, S. Leveneur, Thermal Stability of Epoxidized and Carbonated Vegetable Oils, Org. Process Res. Dev. 20 (2016) 948-953. doi:10.1021/acs.oprd.6b00040.

[27] J.L. Zheng, F. Burel, T. Salmi, B. Taouk, S. Leveneur, Carbonation of Vegetable Oils: Influence of Mass Transfer on Reaction Kinetics, Ind. Eng. Chem. Res. 54 (2015) 10935-10944. doi:10.1021/acs.iecr.5b02006.

[28] M. Blain, L. Jean-Gérard, R. Auvergne, D. Benazet, S. Caillol, B. Andrioletti, Rational investigations in the ring opening of cyclic carbonates by amines, Green Chem. 16 (2014) 42864291. doi:10.1039/C4GC01032A.

[29] H. Tomita, F. Sanda, T. Endo, Model reaction for the synthesis of polyhydroxyurethanes from cyclic carbonates with amines: Substituent effect on the reactivity and selectivity of ring-opening direction in the reaction of five-membered cyclic carbonates with amine, J. Polym. Sci. A Polym. Chem. 39 (2001) 3678-3685. doi:10.1002/pola.10009.

[30] R.M. Garipov, V.A. Sysoev, V.V. Mikheev, A.I. Zagidullin, R.Y. Deberdeev, V.I. Irzhak, A.A. Berlin, Reactivity of cyclocarbonate groups in modified epoxy-amine compositions, Dokl. Phys. Chem. 393 (2003) 289-292. doi:10.1023/B:DOPC.0000003463.07883.c9.

[31] R.M. Garipov, V.V. Mikheev, T.R. Deberdeev, V.I. Irzhak, A.A. Berlin, Study of the curing kinetics for modified epoxy amine systems using model compounds, Dokl. Phys. Chem. 392 (2003) 268-271. doi:10.1023/A:1026190529702. 
[32] M.V. Zabalov, R.P. Tiger, A.A. Berlin, Mechanism of urethane formation from cyclocarbonates and amines: a quantum chemical study, Russ Chem Bull. 61 (2012) 518-527. doi:10.1007/s11172-012-0076-8.

[33] T. Burgel, M. Fedtke, Epoxy-Resins with Cyclic Carbonate Structures - Model Studies for Amine Curing, Polym. Bull. 30 (1993) 61-68. doi:10.1007/BF00296235.

[34] H. Tomita, F. Sanda, T. Endo, Structural analysis of polyhydroxyurethane obtained by polyaddition of bifunctional five-membered cyclic carbonate and diamine based on the model reaction, J. Polym. Sci. Pol. Chem. 39 (2001) 851-859. doi:10.1002/10990518[20010315)39:6<851::AID-POLA1058>3.0.CO;2-3.

[35] D. Couvret, J.C. Brosse, S. Chevalier, J.P. Senet, Acrylic-monomers containing a cyclic carbonate function .2. chemical modification of copolymers with pendent cyclic carbonate groups, Makromol. Chem-Macro. Chem. Phys. 191 (1990) 1311-1319.

[36] V.D. Nemirovsky, S.S. Skorokhodov, Kinetic study of aminolysis of poly(vinylene carbonate) and related model compounds, J. Polym. Sci., C Polym. Symp. 16 (1967) 1471-1478. doi:10.1002/polc.5070160324.

[37] T. Burgel, M. Fedtke, Reactions of Cyclic Carbonates with Amines - Model Studies for Curing Process, Polym. Bull. 27 (1991) 171-177. doi:10.1007/BF00296027.

[38] B. Ochiai, M. Matsuki, T. Miyagawa, D. Nagai, T. Endo, Kinetic and computational studies on aminolysis of bicyclic carbonates bearing alicyclic structure giving alicyclic hydroxyurethanes, Tetrahedron. 61 (2005) 1835-1838. doi:10.1016/j.tet.2004.12.014.

[39] Y. He, V. Goel, H. Keul, M. Moeller, Synthesis, Characterization, and Selectivity of Bifunctional Couplers, Macromol. Chem. Phys. 211 (2010) 2366-2381. doi:10.1002/macp.201000340. 
[40] L. Maisonneuve, A.-L. Wirotius, C. Alfos, E. Grau, H. Cramail, Fatty acid-based (bis) 6membered cyclic carbonates as efficient isocyanate free poly(hydroxyurethane) precursors, Polym. Chem. 5 (2014) 6142-6147. doi:10.1039/C4PY00922C.

[41] M.A. Levina, V.G. Krasheninnikov, M.V. Zabalov, R.P. Tiger, Nonisocyanate polyurethanes from amines and cyclic carbonates: Kinetics and mechanism of a model reaction, Polym. Sci. Ser. B. 56 (2014) 139-147. doi:10.1134/S1560090414020092.

[42] R.H. Lambeth, T.J. Henderson, Organocatalytic synthesis of (poly)hydroxyurethanes from cyclic carbonates and amines, Polymer. 54 (2013) 5568-5573. doi:10.1016/j.polymer.2013.08.053.

[43]D. Swern, T.W. Findley, G.N. Billen, J.T. Scanlan, Determination of Oxirane Oxygen, Anal. Chem. 19 (1947) 414-415. doi:10.1021/ac60006a018.

[44] C. Paquot, Standard methods for the analysis of oils, fats and derivatives, 6th ed., Pergamon Press Ltd., Thiais, 1979.

[45] ISO 3961:1996, Animal and vegetable fats and oils - Determination of iodine value. Multiple. Distributed through American National Standards Institute, 2007.

[46] A. Nicolau, R.M. Mariath, E.A. Martini, D. dos Santos Martini, D. Samios, The polymerization products of epoxidized oleic acid and epoxidized methyl oleate with cis-1,2cyclohexanedicarboxylic anhydride and triethylamine as the initiator: Chemical structures, thermal and electrical properties, Materials Science and Engineering: C. 30 (2010) 951-962. doi:10.1016/j.msec.2010.04.014.

[47] P. Mazo, L. Rios, Carbonation of Epoxidized Soybean Oil Improved by the Addition of Water, J Am Oil Chem Soc. 90 (2013) 725-730. doi:10.1007/s11746-013-2214-3.

[48] I. Javni, D.P. Hong, Z.S. Petrovic, Soy-based polyurethanes by nonisocyanate route, J. Appl. Polym. Sci. 108 (2008) 3867-3875. doi:10.1002/app.27995. 
[49] H. Büttner, C. Grimmer, J. Steinbauer, T. Werner, Iron-Based Binary Catalytic System for the Valorization of $\mathrm{CO}_{2}$ into Biobased Cyclic Carbonates, ACS Sustainable Chem. Eng. 4 (2016) 4805-4814. doi:10.1021/acssuschemeng.6b01092.

[50] K.M. Doll, S.Z. Erhan, Synthesis of Carbonated Fatty Methyl Esters Using Supercritical Carbon Dioxide, J. Agric. Food Chem. 53 (2005) 9608-9614. doi:10.1021/jf0516179.

[51] I. Javni, D.P. Hong, Z.S. Petrović, Polyurethanes from soybean oil, aromatic, and cycloaliphatic diamines by nonisocyanate route, J. Appl. Polym. Sci. 128 (2013) 566-571. doi:10.1002/app.38215.

[52] L. Poussard, J. Mariage, B. Grignard, C. Detrembleur, C. Jérôme, C. Calberg, B. Heinrichs, J. De Winter, P. Gerbaux, J.-M. Raquez, L. Bonnaud, P. Dubois, Non-isocyanate polyurethanes from carbonated soybean oil using monomeric or oligomeric diamines to achieve thermosets or thermoplastics, Macromolecules. 49 (2016) 2162-2171. doi:10.1021/acs.macromol.5b02467.

[53] J.L. Zheng, J. Wärnå, T. Salmi, F. Burel, B. Taouk, S. Leveneur, Kinetic modeling strategy for an exothermic multiphase reactor system: Application to vegetable oils epoxidation using Prileschajew method, AIChE J. 62 (2016) 726-741. doi:10.1002/aic.15037.

[54] S. Leveneur, J. Zheng, B. Taouk, F. Burel, J. Wärnå, T. Salmi, Interaction of thermal and kinetic parameters for a liquid-liquid reaction system: Application to vegetable oils epoxidation by peroxycarboxylic acid, J. Taiwan Inst. Chem. Eng. 45 (2014) 1449-1458. doi:10.1016/j.jtice.2014.01.015.

[55] O. Jogunola, T. Salmi, S. Leveneur, J.-P. Mikkola, Complexation equilibria studies of alkyl formate hydrolysis in the presence of 1-butylimidazole, Thermochimica Acta. 652 (2017) 62-68. doi:10.1016/j.tca.2017.03.012.

[56] H. S. Stoker, General, organic, and biological chemistry, 7th ed., Brooks Cole, Boston, 2015. 
[57] P. S. Deshpande, Chemical modifications of lipids for applications in chemical industry. Ph.D. thesis, North Maharashtra University, 2014.

[58] J. Langanke, L. Greiner, W. Leitner, Substrate dependent synergetic and antagonistic interaction of ammonium halide and polyoxometalate catalysts in the synthesis of cyclic carbonates from oleochemical epoxides and $\mathrm{CO}_{2}$, Green Chem. 15 (2013) 1173-1182. doi:10.1039/C3GC36710J.

[59]M. North, R. Pasquale, Mechanism of Cyclic Carbonate Synthesis from Epoxides and $\mathrm{CO}_{2}$, Angew. Chem., Int. Ed. 48 (2009) 2946-2948. doi:10.1002/anie.200805451.

[60] X.-D. Lang, L.-N. He, Green Catalytic Process for Cyclic Carbonate Synthesis from Carbon Dioxide under Mild Conditions, Chem. Rec. 16 (2016) 1337-1352. doi:10.1002/tcr.201500293.

[61] M. Tryznowski, A. Świderska, Z. Żołek-Tryznowska, T. Gołofit, P.G. Parzuchowski, Facile route to multigram synthesis of environmentally friendly non-isocyanate polyurethanes, Polymer. 80 (2015) 228-236. doi:10.1016/j.polymer.2015.10.055.

[62] L. Meng, Investigation of non-isocyanate urethane functional latexes and carbon nanofiller/epoxy coatings. Ph.D. thesis, The University of Akron, 2015.

[63] H. Haario, MODEST-User's Guide, Profmath Oy, Helsinki, 2001. 